\title{
Impact of Creative Teaching on Science Pupils' Academic Perfomance
}

\author{
Ali Hamdallah ${ }^{1}$, Aliyu Ozovehe ${ }^{2}$ and Leo Dyaji ${ }^{3}$ \\ ${ }^{I}$ Department of Science and Environmental Education, University Of Abuja, Abuja, Nigeria \\ ${ }^{2}$ Trifield Technology limited, Abuja, Nigeria \\ ${ }^{3}$ Department of Science and Environmental Education, University Of Abuja, Abuja, Nigeria
}

\begin{abstract}
This research work sought to establish the effect of creative teaching on science pupil's academic performance as well as encourage primary science teachers in public schools to adopt creative methods of teaching primary science in order to make science interesting and engaging for the pupils. Experimental research design was used in carrying out the investigation. The hypotheses to be tested, using Z-test in this research work are: Creative teaching is not significantly related to academic performance of primary science pupils and usage of instructional material cannot affect creative teaching of primary science. A sample of 75 pupils from Phase III primary school, Gwagwalada Area Council, Federal Capital Teritory (FCT) Abuja, Nigeria were selected for the study. The pupils' were grouped into an experimental and two control groups. The experimental group was taught creatively with instructional materials and the control group A, was taught with instructional material, but were not encourage to explore their originality. The control group B was taught without instructional material, though they were encouraged to express their original ideas creatively. Relevant post test was conducted on twenty five (25) pupils each, for all the groups. The result of the tested hypotheses shows that the null hypotheses were rejected while alternative hypotheses were upheld. It was concluded that to develop a favorable attitude towards the learning of primary science among primary school pupils, there is an urgent need to make learning experience thought provoking through creative teaching.
\end{abstract}

Key words: Academic performance, Creative curriculum, Creativity innovative, Learning, Science teaching and Z-test

\section{Introduction}

Creativity can be described as an essential form of problem solving where there are no easy answers to problems for which popular or conventional responses do not work. Creativity is the consciousness of our original ideas (Jason, 2008 and Moran et. al, 1998 ).Given the paucity of research on pupils in public primary schools and obstacle to their academic performance, there is a pressing need to examine the problems that contribute to primary science pupils' low performance. According to Universal Basic Education (UBE) policy brief, $10^{\text {th }}$ Feb. (2006), academic performance in terms of science pupils' knowledge and skills have deteriorated over the years.

However, the problems associated with primary science pupils' academic performance may be related to: poor teaching methods; lack of qualified teachers; unconducive learning environment; inadequate instructional materials; over populated classes and etceteras. This research study therefore sought to investigate the effects of creative teaching on primary science pupils' academic performance in some selected public primary schools in Gwagwalada Area Council of FCT, Abuja, Nigeria and how creative teaching can address such problems in order to maximize the pupils' intellectual potentials.

The research sought to explore the effects of creative teaching on primary science pupils' academic performance and to establish the effect of creative teaching on the pupil's academic performance as well as encourage primary science teachers in public schools to adopt creative methods of teaching primary science.

\section{Research Hypotheses}

The hypotheses to be tested in this research work are:

- Creative teaching is not significantly related to academic performance of primary science pupils; and

- Usage of instructional material cannot affect creative teaching of primary science. 


\section{Conceptual Framework/Empirical Studies}

Science involves a systematic study of natural phenomenon and it allows pupils to experience the richness and the excitement of the natural world as they engage in inquiry, critical thinking and the demonstration of other skills. The scientific enterprise is one that is challenging and innovative as it blends with technology which focuses on inventions and problem solving. Certainly, when pupils are taught in a creative manner, they will acquire favorable attitude towards such a topic, they will be eager to learn, and they will feel emotionally attached to such teacher who teaches them creatively. While adopting education as instrument per excellence, the Federal Government gave premium on the importance of science and technology and in line with global perspectives of science for all, made provisions for science and technology education in the National Policy on Education.

This however, calls for the need to develop creativity in our primary schools, as a way of developing science education at the primary level and improving primary science pupil's knowledge of science. This is because creativity serves as a process of producing ideas that are novel, useful and meets the need of the people. Creativity is the ability to modify Self-imposed constraints (Ackoff \& Vergara, 1988 cited in Gerard J. Puccio, 2001). This implies that all humans are born with this natural ability to have creative imagination, leading to acquisition of knowledge which may eventually culminate in expertise, if the medium of education is properly used to help pupils acquire creative ideas and behaviour.

Continuity in the production of new ideas, analysis of the ideas and testing the ideas for acceptance or rejection allows for the perfection of creativity (Onu, 2001). This however, can be started with children in primary school. Because when activities are deliberately planned to be stimulating; when children are involved from primary school age in research, problem-solving skills, production of new scientific ideas, inventions, critical and creative thinking skills, the resultant effect is the generation of novel product and innovations. The innovation may not work at the onset with the children, but the pupils will ultimately acquire experiences, and they will improve on their knowledge of primary science.

Many school administrators and teachers realized that it is now time to take more control over the curriculum and to include a greater emphasis on creativity in the teaching and learning of primary science. The reality is that there is a serious lack of qualified teachers. Public schools across the country have for a long time been battling with lack of qualified teachers and accurate data for planning. A report released in 2009 by the World Bank and the Federal Ministry of Education, showed that more than half of the Nigerian primary school teachers were not qualified to teach. According to the report, it is perceived that teaching standards are getting worse by the day. Part of the problems of primary science teaching is that there are many teachers who feel that their lack of scientific background and training disqualifies them from taking science seriously in the classroom. This lack of confidence on the part of the teachers is not unconnected with who become primary science teachers, their background and training.

On the contrary, primary text materials which had increased at a phenomenal rate (with the introduction of the primary integrated science curriculum) were found to contain ideas which primary science teachers have not been exposed to. Ajeyalemi (1987) noted that primary science teaching and the implementation of the new primary science curricula relied more on pupils' reading and memorizing of the textual materials or their note books. In most cases, the Pupils are trained to mainly remember, neither understanding nor thinking, hence they fail to produce and to feel in the true spirit of science.

A particular issue of poor methodology in primary science teaching which is frequently ignored, is that majority of primary school teachers are female. The outcome of which is posing a serious threat to pupils' academic performance. This is because, the female teachers, who in most cases teach primary science, are engaged in motherhood activities, requiring their attentions in an unpredictable pattern or are too occupied with domestic activities and as such are not able to go into much scientific research to develop creative methods or strategies of teaching primary science. Most primary science teachers who are under considerable pressure to 'do some science' tend to be on the lookout for a method which they can apply in a routine fashion to achieve instant success in primary science teaching.

\section{Research Methodology}

The research employed an experimental research design which requires the collection of data from a sample for the purpose of assessing a particular situation presented by the sample. Since the research is concerned with the effects of creative teaching on primary science pupil's academic performance, the researcher used class section practical survey, which is the most effective mechanism that can be used in an experimental research. The research study was carried out on a practical survey to examine the public primary schools in order to analyze the effects of creative teaching on primary science pupils. A sampled population was therefore used as a representative of the general population of the studied area, and also its conclusion was generalized on the population. The population of this research work is made up of 150 pupils in primary one, from Phase III Primary School Gwagwalada, Abuja, Nigeria. 
The sample of the research work consists of seventy five (75) pupils in primary one, randomly selected as representatives of the population. This sample was used as a basis of inference.

The main instrument used for data collection was the lesson note and practical teaching, followed by administered test on three groups of pupils Random collection of test results and observation of primary science pupils was made from the selected public primary schools in Gwagwalada Area Council. It involves teaching three separate groups of pupils in a class and conducting a test to assess the performances of the groups. Textbooks, dramatic stories, models etc, were among the instructional materials used in obtaining the data. The lesson notes was prepared in 3 steps and followed accordingly. The first step explains the concepts being evaluated (difference between domestic and wild animals. The second step shows examples of these animals and the third step briefly describes sounds produced by both domestic and wild animals).

The researcher made several visits to familiarize with the pupils in order to avoid Hawthorne effect. This method was to enable the pupils answer the test questions immediately after each class as administered by the researcher, without restriction and with enough time for normal class test. It saves the researchers time to conduct a class lesson between the experimental group and the control groups so as to assess their performance through a post test.On the fourth visit the main instrument was administered on the groups. The results of the test were collected immediately.

For the collection of data, the pupils were divided into three groups (the experimental group and the two control groups). The pupils in the experimental group were taught creatively using creative and instructional materials such as models of various animals; educational cartoons and etceteras. While those in the control groups A were taught using the normal classroom method (without instructional materials) although attempt were made to teach them creatively, the third group B, were thought with instructional materials but were not engaged in any form of creativity. At the end of each class the researcher provided the groups with the same test problems to be solved based on the topic taught and normal class time for tests. At the end of the lesson, the pupils were evaluated based on the following test questions:

1) Animals that live around us are called .... while animals that live in forest are called

2) Make sounds like the following animals

(a) Goat

(b) Lion

(c) Cat

3) Give 3 examples of domestic animals

4) Mention 2 examples of wild animals

The test results were recorded based on the number of passes and failures accordingly. Scores range from:

14 and above $=$ pass

Below $14=$ fail

\section{Presentation and Analysis of Data}

The Table 1 shows the post test scores of pupils taught creatively, non-creatively with instructional material and the group taught without instructional material but with an attempt to explore their originality. This is to analyze, if pupils taught creatively performed better than those taught non-creatively. The analysis of the hypothesis was done using Z-test ( a statistical test for which the distribution of test statistic under the null hypothesis can be approximated by a normal distribution ).

Table 1: Summary of Pupils' Performance in Experimental and Control Groups

\begin{tabular}{|l|l|l|l|}
\hline Group & No of pupils & No. Pass & No of failure \\
\hline Experimental & 25 & $21(84 \%)$ & $4(16 \%)$ \\
\hline Control A & 25 & $6(24 \%)$ & $19(76 \%)$ \\
\hline Control B & 25 & $4(16 \%)$ & $21(84 \%)$ \\
\hline
\end{tabular}

Note that the pupils were taught the same topics and a test was conducted for each group immediately after each lessons, which is the difference between domestic and wild animals and their examples, the pupils response were subjected to the research hypothesis through the following steps:

- Hypothesis I

Step 1- the appropriate null hypothesis under the post test for control group A.

$\mathrm{H}_{\mathrm{o}}$ - there is no significance difference between the mean score of pupils taught creatively and the mean score of those taught non-creatively with the use of instructional materials. Therefore,

$\mu_{e}-\mu_{c}=0$ 
Where $\mu_{e}$ represents the mean score of the experimental group taught creatively with the

of instructional materials and $\mu_{c}$ represents the mean score of the control group taught non-creatively with the use of instructional materials.

$\mathrm{H}_{\mathrm{a}}$ - there is a significance difference between the mean score of pupils taught creatively and the mean score of those taught non-creatively with the use of instructional materials. Note that equation (1) applies.

Step 2 - level of significance

The null hypothesis was tested at $5 \%(0.05)$ level of significance

Step 3 - computation of test statistics

The mean and standard deviations of the experimental and control group A was subjected

to a post test to differentiate their performance.

Table 2: Mean and Standard Deviation of Experimental and Control Groups A

\begin{tabular}{|l|c|c|}
\hline \multicolumn{1}{|c|}{ Variable } & Experimental & Control Group A \\
\hline Mean & 16.6 & 10.4 \\
\hline Standard Deviation & 4.9 & 5.9 \\
\hline
\end{tabular}

The critical calculated table value of $Z$ for a two-tailed test at 0.05 level of significance is 2.08 , this is because, the $\mathrm{Z}$ - calculated value (4.04) is greater than the given $\mathrm{Z}$-critical value

$(+1.96)$.Therefore, the null hypothesis was rejected.

- Hypothesis II

Step 1 - the appropriate null hypothesis under the post-test for control group B

$\mathrm{H}_{\mathrm{o}}$ - there is no significance difference between the mean score of pupils taught creatively

with instructional materials and the mean score of those taught creatively without instructional materials. Note equation (1) applies.

Step 2 - level of significance

The null hypothesis was tested at $5 \%(0.05)$ level of significance.

Step 3 - computation of test statistics

The mean and standard deviations of the experimental and control group B was subjected post test to differentiate their performances.

Table 2: Mean and Standard Deviation of Experimental and Control Groups B

\begin{tabular}{|l|c|c|}
\hline \multicolumn{1}{|c|}{ Variable } & Experimental & Control Group A \\
\hline Mean & 16.6 & 8.4 \\
\hline Standard Deviation & 4.9 & 5.8 \\
\hline
\end{tabular}

The critical calculated table value of $Z$ for a two-tailed test at 0.05 level of significance is 3.43 , this is because, the $Z$ - calculated value (5.39) is greater than the given $Z$ - critical value $(+1.96)$. Therefore, the null hypothesis is rejected and the alternative hypothesis is upheld.

\section{Discussion of Finding}

The analysis shows that creative teaching and the use of creative instructional materials are related and has effect on primary pupils' academic performances in science. The mean score of 25 pupils tested both in experimental and control groups A and B are 16.6, 10.4 and 8.4 respectively. There is a significant difference between the mean score of primary science pupils taught creatively with instructional materials, and (I) those taught non-creatively with instructional materials, (II) those taught creatively but without instructional materials. Therefore Creative teaching and the use of creative instructional materials are significantly related to the academic performance of primary science pupils. This is in line with Groves, Sawyers and Moran (cited in Sofowora O. A 2007), which suggested that

For a child to grow creatively, he/she must be provided with creative materials. They also state that, for one to motivate and stimulate creativity in children, they must be involved in imaginative play and motivated by internal factors rather than external factors.

The of use creative instructional materials in teaching provides a social climate for evaluation of the lesson learnt. This will in the long run, enhances pupils' creativity. Creativity has actually been seen by some scholars (Russel,1956; Rugg, 1963 and Guilford, 1977), as cited in G., Helstrup, T., \& Teigen, K. H. (1995), to be closely related to problem solving. 
It is difficult to engage the pupils in any creative activities in the absence of instructional material. There are unexploited opportunities to make a real difference to pupils' attitude and knowledge of primary science through the development of creative teaching in public schools. Ali (2011), opined that "if science is to be well related to the pupils environment, they must be encouraged to explore their environment in order to make science more interesting"

\section{Recommendation}

- Creative curriculum should be implemented in public primary schools specifically, in Gwagwalada Area Council and generally in our National educational system. An excellent creative curriculum will generate excitement for both the teachers and pupils to enjoy the process of teaching and learning.

- Pupils should be provided with a conducive learning environment in which they have enough time for creative thinking in order to pave way for recognition of situation and nurture of creativity.

- The government should assist in supplying more valuable and primary science textbooks and creative materials to both the teachers and pupils. The content of such books should conform to the educational objectives set for the pupil's, because, if educational objectives are not in agreement with the content of the textbooks used in teaching primary science, then the objective will be defeated.

- A well equipped nature's garden should be built in each public primary school so as to ensure that pupils' curiosities are aroused.

\section{Conclusion}

The implication of this study to primary science teaching is that when instructional materials are available in a favorable environment, it becomes an obligation for the teachers to engage the pupils creatively. It is also an implication for school administrators to engage themselves in thorough supervision of such practice as well as motivate the teachers towards such practice.

It is an implication for National educational systems in Nigeria, because, if the Federal Government of Nigeria is to achieve the objectives of primary science education they must ensure that the teachers are engaged in holistic training with respect to creative teaching, a certified and promotional program in the teaching career.

The use of creative teaching strategies with creative environment can enhance primary science pupils' academic performance and encourage progressive and creative growth in our pupils without which Nigerian children in the primary schools will not be able to face global challenges and the challenges of the future.

\section{Reference}

[1]. Ajeyalemi, D. (2008), Teaching Expertise: The Road to a Creative Curriculum. Curriculum Reforms and the Nigerian Educational System. Lagos: Jaja, p.147-159.

[2]. Ali H. (2011), "Drinking water health linkage: Implication for Educational Development" Journal of Educational innovators 4 (1) pp 163.

[3]. Babalola, J.B. (2008), "Educational Policy and Planning in Nigeria: Problems and Prospects. In Development and Sustainability in Nigerian Educational System." Proceedings of $2^{\text {nd }}$ National Conference of the Institute of Education, Olabisi Onabanjo University Ago Iwoye. Pp.8-26.

[4]. Banaji S., Burn A. and Buckingham D. (2006), The Rhetoric of Creativity: A Review Of the Literature. London: Centre for the Study of Children, Youth and Media; 2006 (www.creativepartnerships.com/data/files/rhetories-of-creativity-12.pdf, accessed Sept. $(10-2010)$

[5]. Balogun, T.A. and Taiwo, A. A. (1983). Science Activities for Primary Schools, Ibadan: University Press.

[6]. Ehibe S. O. (1999). "Creativity, Science \& Technology and National Development". Paper presented at the conference on actions for Gifted and Talented Children in Nigeria, Suleja, Nigeria.

[7]. Federal Government of Nigeria, (2004), National Policy on Education Abuja NERDC.

[8]. Federal Ministry of Education, (1980), 'Core Curriculum for Primary Science' Lagos:FGN

[9]. Gerard J. Puccio, (2001). Boosting Your Creative Intelligence pucciogj@ buffalostate.edu (716) 878-6223

[10]. Houtz, J.C. (1990), Environment that supports Creative Thinking. In C. Hedley, J. Houtz, \& Baratta (Eds.), Cognition, Curriculum \& Literacy (pp.61-67). Norwood, NJ: Ablex .

[11]. Kaufmann, G., Helstrup, T., \& Teigen, K. H. (1995). Problem solving and cognitive processes: A festschrift in honour of Kjell Raaheim (pp. 145-181).

[12]. Maltizirnan, J. (1960). The Psychology of Creative thinking groups. A source book for Creative Thinking. New York: Bearly Books.

[13]. Moran J.D, Sawyers J.K. and Moore A.J, 1988, "Effects of Structure in Instruction and Materials on Preschool Creativity". Home Economics Research Journal, 17, 148-152.

[14]. Onu, D. (2001), Effects of Bloom's Taxonomy Teaching Strategy on the Cognitive problem solving. New York: Charles Scriber.

[15]. Peter, Lyn, D. \& Linda, N. (2009), Teaching Primary Science: Promoting Enjoyment \& Developing Understanding. London: Longman pp. 320. ISBN 13: 9781405873987.

[16]. Sofowora O. A. (2007). The Use of Educational Cartoons and Comics in Enhancing Creativity in Primary SchoolPupils in Ile-ife, Osun State, Nigeria Journal of Applied Sciences Research, 3(10): 913-920,

[17]. Torrance, E.P. (1978). Creativity in the Classroom, Washington: National Educational Association.

[18]. William, W.C. (1974), "Creativity in Young Children” Journal of Creative Behaviour,(8),101. 